\title{
Chemistry of Calciferol and Vitamin $D_{3}$
}

CALCIFEROL (Windaus's vitamin $\mathrm{D}_{2}$ ) and ergosterol have, according to the view accepted to-day, the formulæ shown in II and I below, respectively.

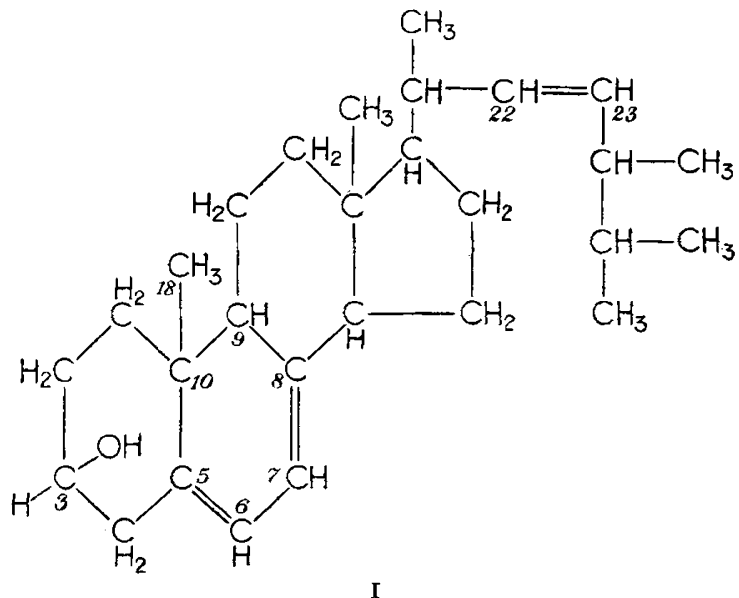

The important common features of the two molecules are :

(a) The possession of two conjugated double bonds at $\mathrm{C}_{5}=\mathrm{C}_{6}$ and $\mathrm{C}_{7}=\mathrm{C}_{8}$.

(b) The possession of a hydrocarbon chain containing a double bond at $\mathrm{C}_{22}=\mathrm{C}_{23}$.

The two substances differ in one fundamental respect, namely, the fracture of ring $B$ between carbon atoms 10 and 9 and the replacement of the methyl group containing carbon atom 18 by a methylene group, with the consequent introduction of a third conjugated double bond between carbon atoms 10 and 18. It is also possible, indeed probable, that the hydroxyl group at carbon atom 3, which is present in ergosterol-and in all other naturally occurring sterols-in the trans position (making the sterols members of the cholestanol series), occupies the cis (epi) position in calciferol. The point seems not yet to be settled.

A series of papers just published by Windaus and his Göttingen colleagues* is another landmark in vitamin chemistry. They report the logical conclusion, or almost the conclusion, of investigations that have been conducted at Göttingen during the past four or five years.

For some time it has been believed, on the basis of differential biological experiments with two species of animals, that the vitamin $\mathrm{D}$ of cod-liver oil is not calciferol. (Bills goes further and maintains that at least two separate antirachitic sub.

- Hoppe-Seyler's Zeitschrift für physiologische Chemie, 241, 100, 104, $116,125,129$ (1936). stances occur in fish-liver oils, in different proportions according to the species of fish.) Attempts to isolate this substance have so far been un. successful, though claims for a very high degree

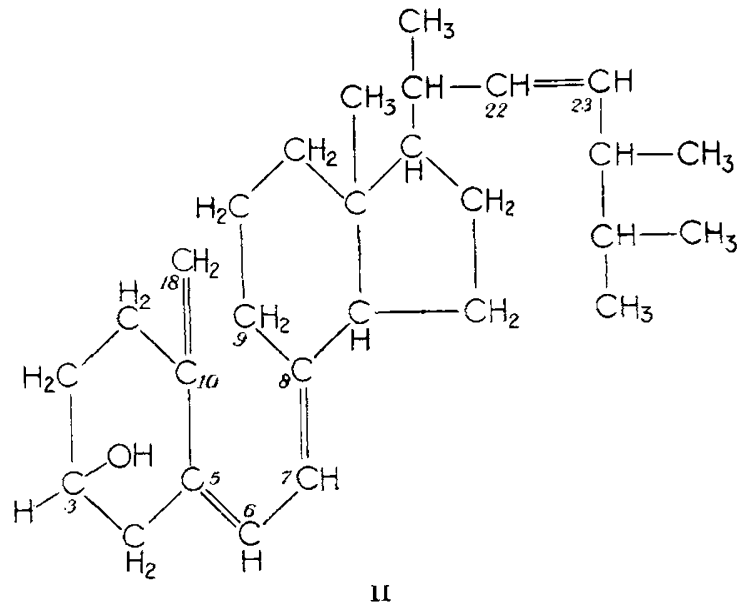

of concentration have been made, notably by Rygh and by Ender.

A erystalline 3,5 dinitrobenzoate of this vitamin, and a colourless non-crystalline preparation of the hydrolytic product from the ester, have now been prepared by Brockmann. The source was tunnyliver oil. The activity of the liquid vitamin is stated to be $25 \times 10^{6} \mathrm{I}$.U. per gram, but it is not inconceivable that traces of impurity may be responsible for its failure to crystallize, and the pure compound may prove to be more active. The absorption spectrum is very similar to that of calciferol, thus disproving Ender's claims for concentration, since his product showed no bands in the ultra-violet. Brockmann argues that Ender's claims must have been overstated by 900 per cent ! In other words, that his preparation cannot have contained as much as 10 per cent of the vitamin and cannot have had more than one tenth of the biological activity claimed by him.

The constitution of this vitamin, for which Brockmann proposes the symbol $\mathrm{D}_{3}$, would not be known but for the brilliant parallel investigations of Windaus, Schenck and Werder, whose results are published alongside Brockmann's. It is now rather more than a year since Windaus, Lettré and Schenck announced the preparation of 7-dehydro-cholesterol ( $\triangle^{5: 6,7: 8}$ cholestadien-3-ol) and stated that it could be made antirachitic by irradiation. They have now isolated the crystalline 3,5 dinitrobenzoate of the active irradiation product, as well as its colourless 
non-crystalline hydrolytic product. Both appear to be in every respect identical with the corresponding substances prepared from tunny-liver oil. It would therefore seem almost beyond doubt that, since 7-dehydro-cholesterol has formula III, the tunny-liver vitamin must be constituted as shown in IV.

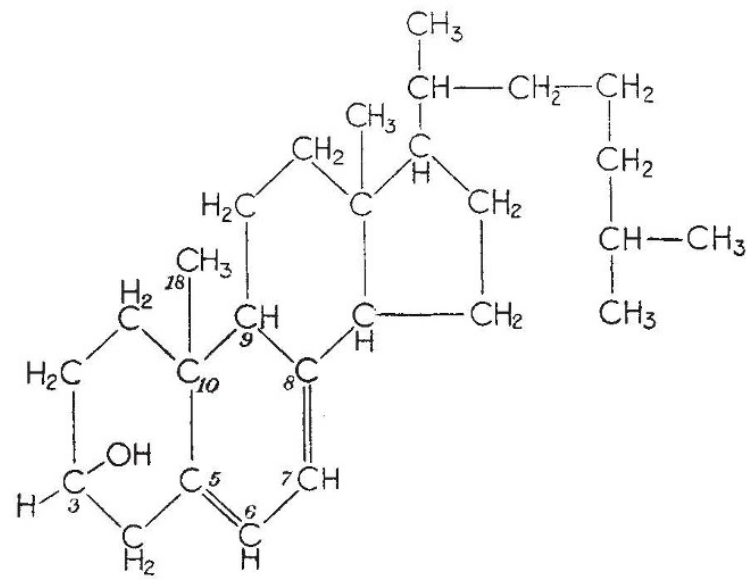

III

If this formula correctly represents the constitution of vitamin $\mathrm{D}_{3}$, it differs from calciferol only in the absence of the double bond at the side-chain position $\mathrm{C}_{22}=\mathrm{C}_{23}$, and the replacement of the terminal side-chain group - $\mathrm{CH}\left(\mathrm{CH}_{3}\right)-\mathrm{CH}\left(\mathrm{CH}_{3}\right)_{2}$ in calciferol by $-\mathrm{CH}_{2}-\mathrm{CH}\left(\mathrm{CH}_{3}\right)_{2}$ in vitamin $\mathrm{D}_{3}$. The physiological differences between the two vitamins must be determined by the differences in the two side-chains which are shown here alongside.

$$
\begin{aligned}
& -\mathrm{CH}\left(\mathrm{CH}_{3}\right)-\mathrm{CH}=\mathrm{CH}-\mathrm{CH}\left(\mathrm{CH}_{3}\right)-\mathrm{CH}\left(\mathrm{CH}_{3}\right)_{2} \\
& \text { Calciferol } \\
& -\mathrm{CH}\left(\mathrm{CH}_{3}\right)-\mathrm{CH}_{2}-\mathrm{CH}_{2}-\mathrm{CH}_{2}-\mathrm{CH}\left(\mathrm{CH}_{3}\right)_{2}
\end{aligned}
$$

This is in itself a quite remarkable finding, but it becomes a mystery when we consider two further investigations reported simultaneously with those summarized above. Wünderlich has prepared 7-dehydrositosterol and irradiated it. The crude irradiation product appears to have only about one fortieth of the antirachitic potency found in irradiated ergosterol, produced presumably under identical conditions. It is not, however, legitimate to argue that the isolated vitamin will have one fortieth the activity of calciferol, since the relative amounts in the two crude irradiation products may be different. If, however, the general course of the photochemical changes is identical, then the vitamin from dehydrositosterol must differ from calciferol and vitamin $\mathrm{D}_{3}$ only in the structure of the side-chain, which is

$$
-\mathrm{CH}\left(\mathrm{CH}_{3}\right)-\mathrm{CH}_{2}-\mathrm{CH}_{2}-\mathrm{CH}\left(\mathrm{C}_{2} \mathrm{H}_{5}\right)-\mathrm{CH}\left(\mathrm{CH}_{3}\right)_{2}
$$

There is, in fact, a replacement by an ethyl group of one hydrogen atom on carbon atom $\mathrm{C}_{24}$ in the side-chain of cholesterol. From the above data it would appear as if the $\mathrm{C}_{22}=\mathrm{C}_{23}$ double bond in calciferol were responsible for its exceptionally potent effect on rachitic rats, compared with that on chickens, and this is borne out by the fact that

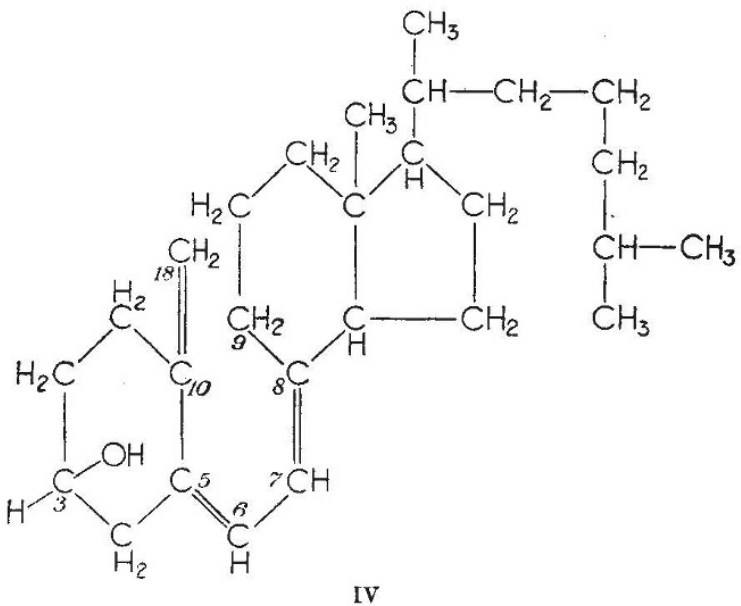

the irradiation product of 22-dihydroergosterol has been reported by Windaus and Langer as having only one thirtieth the activity of irradiated ergosterol. Here again, however, it must be emphasized that crude irradiation products, not distinct crystalline compounds, were being compared. The low activity of irradiated 7-dehydrositosterol may, therefore, be due either to the absence of the $\mathrm{C}_{22}=\mathrm{C}_{23}$ double bond, or to the extra carbon atoms in the side-chain, or to both.

The greatest puzzle, however, arises from a study of 7-dehydrostigmasterol, prepared and irradiated by Linsert. The side-chain of stigmasterol, and therefore presumably of 7-dehydrostigmasterol and its active irradiation product, is

$$
-\mathrm{CH}\left(\mathrm{CH}_{3}\right)-\mathrm{CH}=\mathrm{CH}-\mathrm{CH}\left(\mathrm{C}_{2} \mathrm{H}_{5}\right)-\underset{\text { (Stigmasterol) }}{\mathrm{CH}\left(\mathrm{CH}_{3}\right)_{2}}
$$

Here we have the $\mathrm{C}_{22}=\mathrm{C}_{23}$ double bond associated with the activity of calciferol, and the simple replacement of the ergosterol methyl group at $\mathrm{C}_{24}$ by an ethyl group. According to Linsert, the irradiation product of 7-dehydrostigmasterol is "überraschenderweise" nearly or entirely without any antirachitic action! Yet it is chemically, to all appearances, much more akin to calciferol than any of the other products discussed in this article. Moreover, if 22-dihydroergosterol gives an irradiation product that is very active, though markedly less so than ergosterol, it is inexplicable that 22-dihydro-7-dehydrostigmasterol, which is in fact 7-dehydrositosterol, should give a more antirachitic irradiation product than the stigmasterol derivative. 
The facts relating the side-chain constitution to the antirachitic properties of their irradiation product can be summarized thus :

\begin{tabular}{|c|c|c|c|}
\hline Sterol & $\begin{array}{l}\text { Carbon atoms } \\
\text { in side chain }\end{array}$ & $\begin{array}{l}\text { Double bond } \\
\text { in side chain }\end{array}$ & $\begin{array}{c}\text { Antirachitic } \\
\text { potency }\end{array}$ \\
\hline Dehydrocholesterol & 8 & 0 & ++++ \\
\hline Ergosterol & 9 & 1 & \\
\hline Dihydroergosterol & 9 & 0 & $++t$ \\
\hline Dehydrostigmasterol & 10 & 1 & ? \\
\hline $\begin{array}{l}\text { Dihydrodehydrostigma- } \\
\text { sterol (Dehydrosito- } \\
\text { sterol) }\end{array}$ & 10 & 0 & + \\
\hline
\end{tabular}

It has been suggested by Schoenheimer that the number of carbon atoms in the side-chain has a profound effect on the absorbability of sterols. If this be so, and if it apply also to the irradiation products, the explanation of the facts cited may be found along these lines. Difficulty in accepting such an explanation, however, arises from the fact that ergosterol shows, like sitosterol and other plant sterols, poor absorbability, while cholesterol is very well absorbed, yet the irradiation product of ergosterol is apparently absorbed as easily as that of dehydrocholesterol.

The various papers here summarized are supplemented in the same journal by a very interesting account, from Brockmann and Chen, of an antimony trichloride colour-test for both vitamin $D_{3}$ and calciferol. The authors claim a considerable degree of specificity for the test, and it will doubtless be eagerly tried by many workers in this field.

\section{A. L. Bacharach.}

\section{British Regional Geology}

$\mathrm{I}^{\mathrm{N}}$ the new Museum of the Geological Survey at South Kensington the exhibition of British geology has been arranged on the basis of a division of the country into eighteen districts, each of which forms a geological and geographical province of distinctive type. To each region a separate division of the main floor or first gallery has been assigned, and in order to render the exhibits more intelligible descriptive handbooks have been prepared to serve as guides. These handbooks, issued under the general title of "British Regional Geology", also serve as com. pendious summaries of local geology. Eleven have already been published and these are briefly noticed below.

The Survey is to be warmly congratulated on the success of this important new enterprise. Each handbook is beautifully illustrated with maps, diagrams and plates, and the descriptive matter adequately provides all the necessary detail for a general comprehension of the area concerned. The complete series will constitute the most authoritative and attractive account of British geology as a whole which has ever appeared; one, indeed, that will be indispensable to students for purposes of general study. The individual numbers, issued at the remarkably low price of $1 s$. $6 d$. each, serve as welcome introductions to the more specialized sheet memoirs, and also as guides to tourists and others who wish to appreciate the interest and significance of the geological features of any British district.

"London and Thames Valley" 1 embraces a region from Oxfordshire and north Wilts to Essex and north Kent. It thus comprises beds ranging in age from Lias to Pleistocene and Recent, the main features being the Chalk escarpment of the Chiltern Hills and its continuation west of the Goring Gap, and the middle of the London Basin. Palæozoic formations are known from numerous borings, most of the rocks bearing a general resemblance to those of the Welsh Borders. As in most of the other handbooks of the series, an excellent list of maps and memoirs and a selected bibliography of other publications dealing with the district are appended.

The handbook on "The Wealden District"' covers the area to the south of the above and is probably one of the most familiar geological regions in the world. The Weald proper is continued across the Straits of Dover into the Bas Boulonnais. Beds of many ages are concealed beneath the covering of surface rocks, and at the eastern end of the Weald every system of older stratified rocks from the Silurian upwards is represented, although the complete sequence recognized has not been found in any one boring. A very clear diagrammatic section is given showing the active collieries and working seams of the Kent Coalfield. Water, however, is fundamentally the most important of the economic resources of the Wealden District, since practically all that is used is derived from underground sources.

"Bristol and Gloucester District"3 extends from the Forest of Dean across the Severn to the Cotteswold and Mendip Hills. Geologically speaking, it is one of the most varied districts of Britain, for, with the exception of the Ordovician 